\title{
Adsorption isotherms and kinetics of HFC410A onto activated
}

\section{carbons}

\author{
Ahmed A. Askalany ${ }^{\mathrm{a}, *}$, Bidyut B. Saha $^{\mathrm{b}, \mathrm{c}, *}$, Ibrahim M. Ismail $^{\mathrm{d}}$ \\ ${ }^{\mathrm{a}}$ Mechanical Engineering Department, Faculty of Industrial Education, Sohag University, \\ Sohag, 82524, Egypt \\ ${ }^{\mathrm{b}}$ Interdisciplinary Graduate School of Engineering Sciences, Kyushu University, 6-1 Kasuga- \\ Koen, Kasuga-Shi, Fukuoka 816-8580, Japan \\ ${ }^{c}$ International Institute for Carbon-Neutral Energy Research (WPI-I2CNER), Kyushu \\ University \\ ${ }^{\mathrm{d}}$ Mechanical Engineering Department, Faculty of Engineering, Assiut University, Assiut \\ 71515, Egypt \\ *Corresponding Authors, Tel: +20-862370572, E-mail: ahmed askalany3@yahoo.com (AAA), \\ Tel: +81-92-583-7903, E-mail: saha.baran.bidyut.213@m.kyushu-u.ac.jp (BBS).
}

\begin{abstract}
Experimental and theoretical adsorption isotherms and kinetics data of HFC410A onto activated carbons are reported. Activated carbon powder of type Maxsorb III and activated carbon fiber of type A-20 have been used as adsorbents. An experimental apparatus has been designed and built and experimental investigation has been carried out at five adsorption temperatures in the range of $10-50^{\circ} \mathrm{C}$. Experimental data has been fitted with Tóth and Dubinin-Astakhov (D-A) adsorption isotherm models and linear driving force (LDF) adsorption kinetics model. A range of adsorption parameters such as isosteric heat of adsorption, adsorption uptake and temperature dependence and Henry's law coefficients are
\end{abstract}


evaluated. A correlation between Henry's law coefficients and isosteric heat of adsorption at limiting uptake is analyzed.

Keywords; Activated carbon, adsorption, heat of adsorption, HFC410A

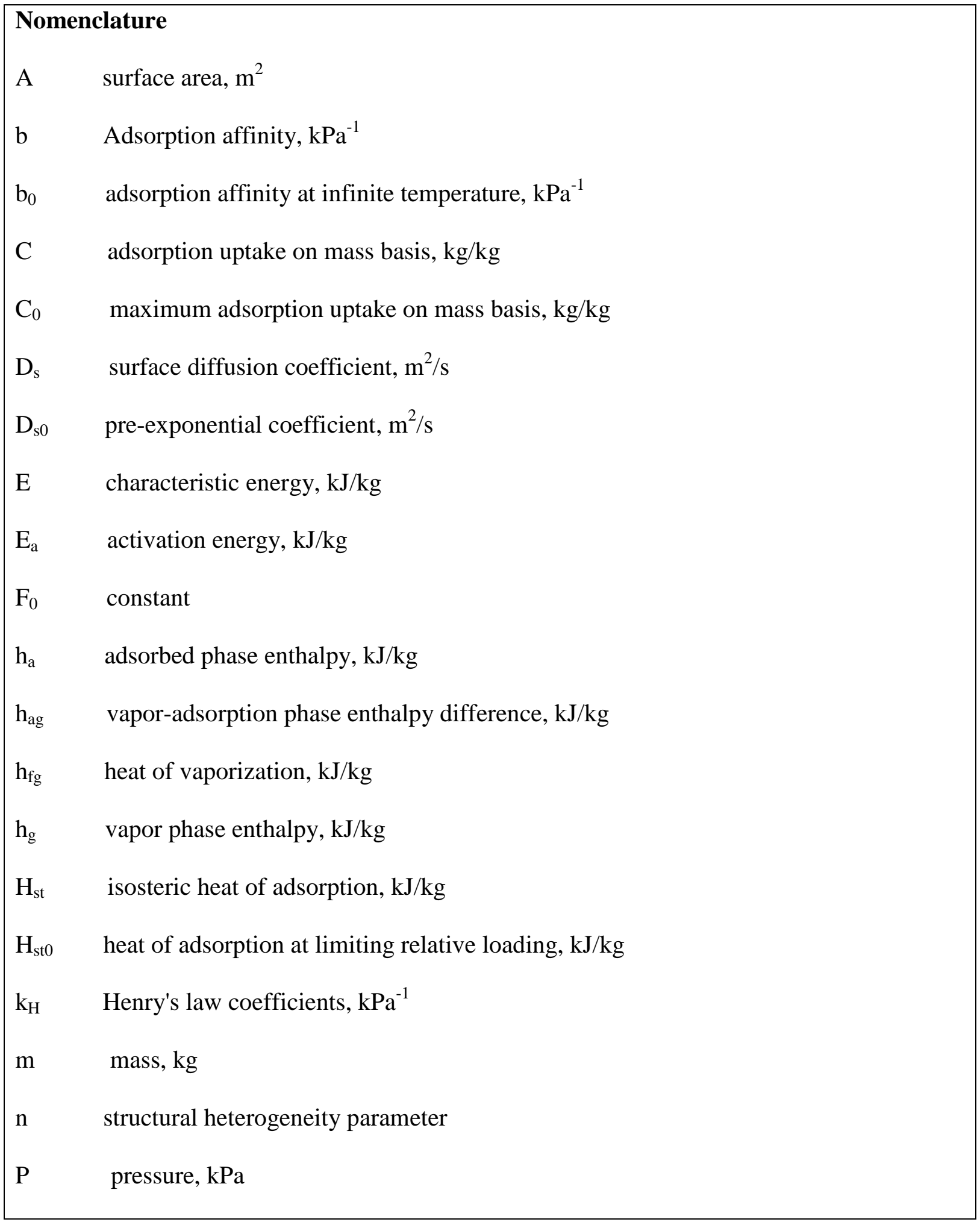




\begin{tabular}{|c|c|}
\hline $\mathrm{P}_{\mathrm{s}}$ & saturation pressure, $\mathrm{kPa}$ \\
\hline $\mathrm{R}$ & universal gas constant, $\mathrm{kJ} / \mathrm{kmole} . \mathrm{K}$ \\
\hline $\mathrm{R}_{\mathrm{gas}}$ & gas constant, $\mathrm{kJ} / \mathrm{kg} . \mathrm{K}$ \\
\hline $\mathrm{R}_{\mathrm{p}}$ & particle radius, $\mathrm{m}$ \\
\hline $\mathrm{Z}$ & micro pore distribution parameter \\
\hline $\mathrm{T}$ & temperature, $\mathrm{K}$ \\
\hline $\mathrm{t}$ & time, $\mathrm{s}$ \\
\hline V & volume, $\mathrm{m}^{3}$ \\
\hline $\mathrm{V}_{\mathrm{a}}$ & adsorbed phase volume, $\mathrm{m}^{3} / \mathrm{kg}$ \\
\hline $\mathrm{W}_{0}$ & total pore volume, $\mathrm{m}^{3} / \mathrm{kg}$ \\
\hline$\alpha_{\mathrm{g}}$ & thermal expansion coefficient of gas phase, $\mathrm{K}^{-1}$ \\
\hline$\rho$ & density, $\mathrm{kg} / \mathrm{m}^{3}$ \\
\hline \multicolumn{2}{|c|}{ Subscript } \\
\hline ads & adsorbent \\
\hline ads & adsorbent \\
\hline ads cell & adsorption cell \\
\hline $\mathrm{f}$ & final \\
\hline in & initial \\
\hline $\mathrm{j}$ & number of measurement \\
\hline load & load cell \\
\hline pore & pore \\
\hline sol & solid \\
\hline tube & tube \\
\hline void & void \\
\hline
\end{tabular}




\section{Introduction}

As global warming becoming an increasingly serious issue, the existing high GWP (global warming potential) based refrigerants must be disposed safely before replacing those by natural refrigerants or relatively lower GWP based refrigerants. Adsorption technology is considered one of the most effective ways to capture and store the residual gases [1-4].

The adsorption isotherms and kinetics of several greenhouse gases such as HFC134A [5], HFC507A [6], HFC32 [7] and $\mathrm{CO}_{2}$ [8] have been investigated experimentally and theoretically. However, enough data are not available in open literature on the adsorption isotherms and kinetics of HFC410A on to highly porous activated carbon powder (ACP) and activated carbon fiber (ACF).

HFC410A is a near-azeotropic mixture of difluoromethane $\left(\mathrm{CH}_{2} \mathrm{~F}_{2}\right.$, called $\left.\mathrm{HFC} 32\right)$ and pentafluoroethane $\left(\mathrm{CHF}_{2} \mathrm{CF}_{3}\right.$, called $\left.\mathrm{HFC} 125\right)$ of equal mass fraction. It will be phased out within several years according to the IPCC $4^{\text {th }}$ assessment report [9]. It may be replaced by new low GWP based refrigerants such as $\mathrm{CO}_{2}$, $\mathrm{HFO} 1234 \mathrm{ze}(\mathrm{E})[8,10]$. Table 1 shows the ODP, GWP and normal boiling temperature of several HFCs and HFOs.

HFC410A has been used as a refrigerant in old fashion air conditioning systems. Adsorption data on HFC410A are expected to be beneficial for possible thermal compression, separation of the mixtures at the end of the life cycle and capture of the mixture to replace it. Loh et al. [11] studied the adsorption isotherms of HFC410A onto ACP of type Maxsorb III. The presented data at that study focused only on adsorption uptake and heat of adsorption of Maxsorb III/HFC410A.

In addition to the adsorption uptakes and heat of adsorption of activated carbon powder of type Maxsorb III/HFC410A, this study presents the adsorption kinetics and other important parameters such as Henry's law coefficients and heat of adsorption at limiting 
relative loading. Moreover, the adsorption isotherms, heat of adsorption, Henry's law coefficients, relation between $\mathrm{kH}$ and $\mathrm{Hst} \mathrm{O}$ and adsorption kinetics of activated carbon fiber of type A-20/HFC410A have been presented. These data are essential in designing of adsorption heat pump and storage systems.

\section{Experimental apparatus}

\subsection{Description}

The experimental apparatus as shown in Fig. 1 consists mainly of an adsorption cell and a load cell settled inside two different water baths. Two water circulators with an external plumbing are conducted to attain homogeneous temperatures inside the water baths. Seven valves are installed at different locations of the experimental apparatus in order to control the flow of adsorbate. The adsorption and load cells are made of stainless steel (SUS 304) with 2.5 liter volume for each cell. A copper tube coil with a diameter of $1 / 8$ inch has been fabricated inside the adsorption cell to improve heat transfer (heating or cooling) of the adsorption cell. The copper coil is connected to an individual water circulator with heater and cooler. A circular mesh has been installed inside the adsorption cell to prevent migration of activated carbon particles. A Corilios gas flow meter has been located between the adsorption and load cells to measure flow rate of the adsorbate. The experimental apparatus has been connected to a vacuum pump which has been used for evacuation purposes. Series of type K thermocouples with an accuracy of $\pm 0.1^{\circ} \mathrm{C}$ are attached at different locations all over the test rig to detect temperatures. Pressure transducers are used to measure the pressures of the adsorption and load cells and the evaporator with an accuracy of $\pm 0.25 \%$ of the full scale reading. 


\subsection{Procedure}

Before starting the experimental runs, the adsorbent are prepared by heating it up to $100^{\circ} \mathrm{C}$ for six hours to ensure no moisture content. The adsorbent has been assembled inside the adsorption cell after weighting it by using $\pm 0.05 \mathrm{~g}$ accuracy weighting balance. The volume of adsorption cell, load cell and connecting tubes are determined by filling water method. To start adsorption process, the whole system has been evacuated until the pressure become as low as $25 \mathrm{~Pa}$ inside the adsorption and load cells. The load cell is then loaded by HFC410A to a certain pressure where the adsorption process is managed for different progressive pressures. Pressure inside the load cell has not allowed exceeding the saturation pressure at the desired adsorption temperature in order to prevent condensation of the HFC410A. After obtaining stable conditions of initial pressure and temperature at the load cell, the adsorption process starts by opening valves between load and adsorption cells. After equilibrium, the valves are closed. This process is repeated many times by raising the pressure of the load cell every time at same adsorption temperature.

The experimental adsorption process is repeated for various temperatures in the range of $10-50^{\circ} \mathrm{C}$. The maximum adsorption temperature has been decided to be less than the critical temperature of the refrigerant which is $70.17^{\circ} \mathrm{C}$ in case of $\mathrm{HFC} 410 \mathrm{~A}$.

\subsection{Martials}

Activated carbon powder (ACP) of type Maxsorb III and activated carbon fiber (ACF) of type A-20 have been used as adsorbents in the present study. Table 2 shows the specifications of the used adsorbents [12, 13]. 


\section{Data extraction}

The collected data of the present experimental work are mainly the pressure and temperature of the cells and the mass flow rate of the adsorbate. However, the most important data is the uptake amount (adsorption capacity) of the refrigerant by adsorbent which has been determined by the volumetric method. In order to determine the adsorbed amount of refrigerant at certain adsorption temperature, equations from 1 to 4 are used.

$$
\begin{aligned}
& m_{j}=m_{j-1}+\Delta m_{\text {load }, j}-\Delta m_{\text {void }, j} \\
& \Delta m_{\text {load }, j}=\left(\rho_{\text {in }}-\rho_{f}\right)_{\text {load }}\left(V_{\text {load }}+V_{\text {tube }}\right) \\
& \Delta m_{\text {void }, j}=\left(\rho_{a d s, j}-\rho_{\text {ads }, j-1}\right)_{\text {ads cell }}\left(V_{\text {void }}\right) \\
& V_{\text {void }}=V_{\text {ads }}-\left(\frac{m_{\text {ads }}}{\rho_{\text {sol }}}+V_{\text {pore }}\right)
\end{aligned}
$$

\section{Theoretical models}

Many theoretical adsorption isotherms and kinetics models have been driven to simulate and predict the behavior of a certain adsorption/refrigeration pair. In order to determine the adjacent parameters of the different adsorption isotherms and kinetics models, the experimental results have been fitted with Tóth model and Dubinin-Astakhov (D-A) model with volume correction for adsorption isotherms and linear driving force (LDF) model for adsorption kinetics. 


\subsection{Tóth isotherm}

This model can be expressed in Eq. 5 which is shown below [14].

$$
\begin{aligned}
& \frac{\mathrm{C}}{\mathrm{C}_{\circ}}=\frac{b P}{\left[1+(b P)^{t}\right]^{\frac{1}{z}}} \\
& \mathrm{~b}=b_{\circ} e^{\left(\frac{H_{s t}}{R T}\right)}
\end{aligned}
$$

\subsubsection{D-A model with volume correction}

The D-A with volume correction is shown in Eq. 7, below [15].

$$
C=\frac{w_{\circ}}{v_{a}} \exp \left\{-\left[\frac{R_{\text {gas }} T}{E} \ln \left(\frac{P_{s}}{P}\right)\right]^{n}\right\}
$$

The absolute adsorption $C$ is derived from the measured data. The adsorbed phase volume $\left(v_{a}\right)$ is calculated using the law of rectilinear diameters approach proposed by Srinivasan et al. [16].

$v_{a}=\left[A-B T-\frac{1}{v_{g}}\right]^{-1}$

$v_{g}$ is the gas phase specific volume at the equilibrium pressure and temperature. $p_{s}$ and $v_{g}$ are calculated using REFPROP [17].

Considering the uncertainties in the measurement of all physical quantities such as temperature, pressure, mass of adsorbent, volumes of cells and effect of plumb line volume, the estimated uncertainty in the whole range of data are below $\pm 5 \%$. 


\subsubsection{Isosteric heat of Adsorption}

Isosteric heat of adsorption of an adsorbent/adsorbate pair is an essential variable for designing a practical gas storage systems or adsorption cooling systems. This section presents evaluation of the isosteric heat of adsorption of HFC410A onto ACP and ACF type adsorbents.

Isosteric heat of adsorption is traditionally expressed as a function of concentration as its dependence on temperature is relatively weak [18, 19]. Clausius-Clapeyron equation is commonly used to estimate heat of adsorption assuming ideal gas at constant concentration as given by Eq. 9 .

$H_{s t}=\frac{-R \partial \ln P}{\partial(1 / T)}$

The analysis of the isosteric heat of adsorption starts using the D-A equation which could be rewritten in the form of Eq. 10.

$\ln P=\ln P_{S}-\frac{E}{R T} \ln \left(\frac{W_{0}}{C V_{a}}\right)^{\frac{1}{n}}$

$h_{f g}=\left.\frac{-R \partial \ln P_{S}}{\partial(1 / T)}\right|_{C}$

$H_{s t}=h_{f g}+E\left[\ln \left(\frac{W_{0}}{C v_{a}}\right)\right]^{\frac{1}{n}}+\frac{E T \alpha}{n}\left[\frac{\ln \left(W_{0}\right)}{C V_{a}}\right]^{\frac{1-n}{n}}$

$\alpha=v_{a}\left(B-\frac{\alpha_{g}}{v_{g}}\right)$

The thermal expansion coefficient of the gas phase $\left(\alpha_{g}\right)$ and the heat of vaporization $\left(h_{f g}\right)$ are obtained from REFPROP. 


\subsection{LDF model}

One of the widely used models in simulating the kinetics of the adsorption process is the LDF model which is presented below by Eq. 14 .

$\frac{c-c_{\text {in }}}{c_{0}-c_{\text {in }}}=1-\exp \left[-k_{s} a_{v}\left(t-t_{\text {in }}\right)\right]$

$k_{s} a_{v}=F_{0} \frac{D_{s}}{R_{p}^{2}}$

Ruthven [20] reported that, during the initial phase of adsorption, surface diffusion coefficient follows the uptake behavior of a semi-infinite medium of any particle shape and can be expressed as,

$\frac{C}{C_{0}}=\frac{2 A}{V} \sqrt{\frac{D_{s} t}{\pi}}$

A plot of relative uptake and square root of time yields with a slope of $\frac{2 A}{V} \sqrt{\frac{D_{S}}{\pi}}$. So that the values of the surface diffusion could be extracted which are expressed as [21]:

$D_{s}=D_{s 0} \exp \left(\frac{-E_{a}}{R_{g} T}\right)$

Which can be arranged as,

$\ln \left(D_{s}\right)=\ln \left(D_{s 0}\right)-\frac{E_{a}}{R_{g} T}$

By plotting $\ln \left(D_{s}\right)$ against $1 / T$, one can get the numerical values of activation energy, $E_{a}$ in $\mathrm{kJ} / \mathrm{kg}$ and the pre-exponential coefficient, $D_{s 0}$ in $\mathrm{m}^{2} / \mathrm{s}$. This plot is known as Arrhenius plot. The slope yields $-E_{d} / R_{g}$ where $R_{g}$ is the gas constant in $\mathrm{kJ} / \mathrm{kg}$ and the intercept provides $D_{s} 0$ [22]. 


\section{Results and discussion}

Figures 2 and 3 show the adsorption uptakes of ACP/HFC410A and ACF/HFC410A adsorption pairs, respectively. These figures show the adsorption capacity in $\mathrm{kg} / \mathrm{kg}$ on the basis of the adsorption pressure at various adsorption temperatures ranging from $10^{\circ} \mathrm{C}$ to $50^{\circ} \mathrm{C}$. The solid lines in the figures are indications for the D-A with volume correction and the dashed lines are indications for the Tóth equation, while the symbols are indications for the experimental results. Both Figs. 2 and 3 show that D-A and Tóth equations agree well with the present experimental adsorption isotherms data. However, the best agreement between the experimental and theoretical results could be seen with the D-A model. These figures indicate that the adsorption capacity of HFC410A on to ACP is 1.6 times higher than that of the ACF. This is because the relatively higher surface area and pore volume of $\mathrm{ACP}$, which are about 1.6 times of those of the ACF.

Figure 4 shows the difference between experimental and calculated adsorption uptakes of HFC410A onto ACP and ACF. This figure shows that both theoretical isotherm models fit the experimental data within error range of $\pm 5 \%$.

Table 3 gives Tóth isotherm parameters for ACP/HFC410A and ACF/HFC410A which have been obtained from the fitting between experimental and theoretical data. Table 4 introduces the fitting parameters of D-A equation with volume correction. The parameters $\mathrm{A}$ and $\mathrm{B}$ have been determined to be 0 and 0.0015 respectively for both ACP/HFC410A and ACF/HFC410A.

Figure 5 shows the maximum adsorption capacity based on Tóth equation for HFC410A, HFC32 and $\mathrm{CO}_{2}$ onto ACP and ACF adsorbents [7, 8]. This figure indicates that ACP/HFC410A could achieve the highest adsorption capacity comparing to the other adsorption pairs. 
Figure 6 and Figure 7 show the isosteric heats of adsorption which are obtained from the D-A equation at various adsorption temperatures for ACP/HFC410A and ACF/HFC410A respectively. The isosteric heat of adsorption has a reverse relationship with the temperature with respect to the relative capacity. These figures show that the isosteric heat of adsorption decreases by increasing the adsorption capacity, which means increasing either the adsorption capacity or the adsorption temperature, decreases the isosteric heat of both ACP/HFC410A and $\mathrm{ACF} / \mathrm{HFC} 410 \mathrm{~A}$ adsorption pairs.

A logarithmic relation between $H_{s t}$ and $C v_{a} / W_{0}$ is found to describe their interdependence along each isotherm mathematically which can be expressed as:

$$
H_{s t}=H_{s t 0}+\beta \ln \left(\frac{C v_{a}}{W_{0}}\right)
$$

The temperature dependences of $H_{s t 0}$ and $\beta$ are plotted in Fig. 8. A polynomial equation of second order describes the temperature dependence of $H_{s t 0}$ while $\beta$ seems to be fairly independent of temperature. Hence Eq. 19 is generalized as follows:

$$
H_{s t}=A_{1} T^{2}+A_{2} T+A_{3}+\beta \ln \left(\frac{C v_{a}}{W_{0}}\right)
$$

The numerical values of $A_{1}, A_{2}, A_{3}, \beta$ are listed in Table 5. Difference between the vapor phase enthalpy $\left(h_{g}\right)$ and adsorbed phase enthalpy $\left(h_{a}\right)$ has been calculated. However $h_{a}$ has been determined using REFPROP based on the adsorbed phase volume $\left(v_{a}\right)$. Figure 8 shows the temperature dependence of vapor-adsorption phase enthalpy difference $\left(h_{a g}\right)$. It has been found that the ACP/HFC410A and ACF/HFC410A has same values for $h_{a g}$. A polynomial equation of second order is found to describe the temperature dependence of $h_{a g}$ as below;

$h_{a g}=-0.0143 \times T^{2}+6.5975 \times T-526.03$ 
From Eq. 12 it can be seen that the heat of adsorption at limiting relative loading $\left(C v_{a} / W_{0}=1\right)$ is $H_{s t}$. It may be recalled that D-A isotherm does not have a Henry's law regime [23]. On the other hand, the Tóth isotherm does not depict a limiting pressure. Akkimaradi et al. [24] and Wang et al. [25] linked these two isotherms through Henry's law coefficient derived from Tóth isotherm and the isosteric heat of adsorption derived from D-A isotherm at limiting loading condition. Tóth equation yields the temperature dependence of the Henry's law coefficients straight away.

$k_{H}=\left.\underset{\mathrm{p} \rightarrow 0}{\mathrm{Lt}} \frac{\partial C}{\partial p}\right|_{T}=C_{0} b_{0} \exp \left(\frac{H_{s t}}{R T}\right)$

Figure 9 shows the relation between $k_{H}$ and $1 / T$ based on Eq. 17. Figure 10 shows an increasing trend of $H_{s t}$ with respect to $k_{H}$ for both ACP/HFC410A and ACF/HFC410A pairs. Empirical cubic equations relating $H_{s t}$ and $k_{H}$ are given below for ACP/HFC410A and ACF/HFC410A, respectively.

$H_{s t 0}=7 \times 10^{8}\left(k_{H}\right)^{3}-2 \times 10^{7}\left(k_{H}\right)^{2}+117902\left(k_{H}\right)-161.3$

$H_{s t 0}=10^{9}\left(k_{H}\right)^{3}-2 \times 10^{7}\left(k_{H}\right)^{2}+111125\left(k_{H}\right)-124.19$

Mathematical description of isotherms derived from experimental data together with other supplementary properties such as isosteric heat of adsorption and Henry's law coefficient extracted from those isotherms would be the primary information required for designing of adsorption storage system.

Figures 11 and 12 show the experimental adsorption capacity fitting by LDF model at different adsorption temperatures for ACP/HFC410A, and ACF/ HFC410A, respectively. These figures show relatively good agreement between the experimental data and the LDF model results. Table 6 shows the activation energy and pre-exponential coefficient values for ACP/HFC410A and ACF/HFC410A pairs. 


\section{Conclusions}

The adsorption isotherms and kinetics of HFC410A onto ACP and ACF have been studied. An apparatus has been designed and built in order to conduct the experimental investigations. The maximum adsorption capacity of the ACP is found to be 1.6 times higher than that of $\mathrm{ACF}$ at same adsorption temperature. Both investigated adsorption isotherms (Tóth, D-A) models and kinetics (LDF) models have been found to fit the experimental data within $\pm 5 \%$ deviations. The isosteric heat of adsorption data for ACP/HFC410A and ACF/HFC410A pairs have been determined based on D-A equation. Heats of adsorption at limiting relative loading and Henery's law coefficient have been determined for the studied adsorbent/refrigerant pairs. Empirical equations for the relation between temperature and heats of adsorption at limiting relative loading have been presented.

\section{Acknowledgements}

This work was financially supported by Japan Science and Technology Agency (JST) and Core Research Evolution Science and Technology (CREST). 


\section{References}

[1] G. Hermosilla-Laraa, G. Momena, P.H. Marty, B. Le Neindre, K. Hassouni, Hydrogen storage by adsorption on activated carbon: Investigation of the thermal effects during the charging process, Int. J. Hydrogen Energy 32 (2007) 1542-1553.

[2] P. Malbrunot, D. Vidal, J. Vermesse, Storage of gases at room temperature by adsorption at high pressure, Appl. Therm. Eng. 16 (5) (1996) 375-382.

[3] J.P. Barbosa Mota, A.E. Rodrigues, E. Saatdjian, D. Tondeur, Dynamics of natural gas adsorption storage systems employing activated carbon, Carbon 35 (9) (1997) 1259-1270.

[4] D. Stitou, N.E. Mazet, S. Mauran, Experimental investigation of a solid/gas thermochemical storage process for solar air-conditioning, Energy, 41 (1) (2012) 261-270.

[5] A.A. Askalany, M. Salem, I.M. Ismail, A.H.H. Ali, M.G. Morsy, Experimental study on adsorption-desorption characteristics of granular activated carbon/R134a pair, Int. J. Refrig. 35 (3) (2012) 494-498.

[6] K. Habib, B.B. Saha, K.A. Rahman, A. Chakraborty, S. Koyama, K.C. Ng, Experimental study on adsorption kinetics of activated carbon/R134a and activated carbon/R507A pairs, Int. J. Refrig. 33 (4) (2010) 706-713.

[7] A.A. Askalany, B.B. Saha, K. Uddin, T. Miyzaki, S. Koyama, K. Srinivasan, I.M. Ismail 2013. Adsorption isotherms and heat of adsorption of difluoromethane on activated carbons, $\mathrm{J}$. Chem. Eng. Data, 58 (10) (2013) 2828-2834.

[8] B.B. Saha, S. Jribi, S. Koyama, I.I. El-Sharkawy, Carbon dioxide adsorption isotherms on activated carbons, J. Chem. Eng. Data 56 (5) (2011) 1974-1981. 
[9] P. Forster, V. Ramaswamy, P. Artaxo, T. Berntsen, R. Betts, D.W. Fahey, J. Haywood, J. Lean, D.C. Lowe, G. Myhre, J. Nganga, R. Prinn, G. Raga, M. Schulz, R. Van Dorland, Changes in atmospheric constituents and in radiative forcing. In: Climate Change: The Physical Science Basis (2007).

[10] S. Jribi, B.B. Saha, S. Koyama, A. Chakraborty, K.C. Ng, Study on activated carbon/HFO-1234ze(E) based adsorption cooling cycle, Appl. Therm. Eng. 50 (2) (2013) 1570-1575.

[11] W.S. Loh, A.B. Ismail, B. Xi, K.C. Ng, W.G. Chun, Adsorption Isotherms and Isosteric Enthalpy of Adsorption for Assorted Refrigerants on Activated Carbons, J. Chem. Eng. Data 57 (2012) 2766-2773.

[12] I.I. El-Sharkawy, K. Kuwahara, B.B. Saha, S. Koyama, K.C. Ng, Experimental investigation of activated carbon fibers/ethanol pairs for adsorption cooling system application, Appl. Therm. Eng. 26 (2006) 859-865.

[13] W.S. Loh, K.A. Rahman, A. Chakraborty, B.B. Saha, Y.S. Choo, B.C. Khoo, K.C. Ng, Improved isotherm data for Adsorption of methane on activated carbons, J. Chem. Eng. Data 55 (2010) 2840-2847.

[14] S. Himeno, T. Komatsu, S. Fujita, High pressure adsorption equilibria of methane and carbon dioxide on several activated carbons, J. Chem. Eng. Data 50 (2005) 369-376.

[15] B.B. Saha, S. Koyama, I.I. El-Sharkawy, K. Habib, K. Srinivasan, P. Dutta, Evaluation of adsorption parameters and heats of adsorption through desorption measurements, J. Chem. Eng. Data 52 (2007) 2419-2424.

[16] K. Srinivasan, B.B. Saha, K.C. Ng, P. Dutta, M. Prasad, A method for the calculation of the adsorbed phase volume and pseudo-saturation pressure from adsorption isotherm data on activated carbon, Phys. Chem. Chem. Phys. 13 (2011) 12559-12570. 
[17] E.W. Lemmon, M.L. Huber, M.O. McLinden, REFPROP, Reference Fluid Thermodynamic and Transport Properties, NIST Standard Reference Data Base 23 (9)(2010).

[18] B.S. Akkimaradi, M. Prasad, P. Dutta, K. Srinivasan, Adsorption of 1,1,1,2tetrafluoroethane on Activated Charcoal, J. Chem. Eng. Data. 46 (2001) 417-422.

[19] M. Prasad, B.S. Akkimaradi, S.C. Rastogi, R. Rao, K. Srinivasan, Heat of adsorption for charcoal-nitrogen systems, Carbon 37 (1999) 1641-1642.

[20] D. M. Ruthven, Principles of adsorption and adsorption processes", John Willy \& Sons, Inc., (1984) 128-130.

[21] B.B. Saha, I.I. El-Sharkawy, A. Chakraborty, S. Koyama, Study on an activated carbon fiber e ethanol adsorption chiller: Part I- system description and modeling. Int. J. Refrig. 30 (2007) 86-95.

[22] K. Habib, B.B. Saha, K.A. Rahman, A. Chakraborty, S. Koyama, K.C. Ng, Experimental study on adsorption kinetics of activated carbon/R134a and activated carbon/R507A pairs. Int. J. Refrig. Volume 33, Issue 4, June 2010, Pages 706-713.

[23] B.J. Schindler, L.C. Buettner, M.D. LeVan, Transition to Henry's law in ultra-low concentration adsorption equilibrium for n-pentane on BPL activated carbon, Carbon 46 (2008) 1285-1293.

[24] B.S. Akkimaradi, M. Prasad, P. Dutta, B.B. Saha, K. Srinivasan, Adsorption of Nitrogen on Activated Carbon-Refit of Experimental Data and Derivation of Properties Required for Design of Equipment, J. Chem. Eng. Data 54 (2009) 2291-2295.

[25] X. Wang, J. French, K. Srinivasan, H.T. Chua, Adsorption measurements of methane on activated carbon in 281 to $343 \mathrm{~K}$ and pressures to $1.2 \mathrm{MPa}$, J. Chem. Eng. Data 55 (2010) 2700-2706. 
Table captions:

Table 1. ODP, GWP and boiling temperature of some HFCs refrigerants.

Table 2. Specifications of the adsorbents.

Table 3. Fitting parameters of Tóth equation.

Table 4. Fitting parameters of D-A equation.

Table 5. Fitting parameters for combined temperature and loading dependence heat of adsorption.

Table 6. Activation energy and pre-exponential coefficient for ACP/HFC410A and $\mathrm{ACF} / 410 \mathrm{~A}$. 
Table 1. ODP, GWP and boiling temperature of some HFCs refrigerants.

\begin{tabular}{|c|c|c|c|}
\hline Refrigerant & ODP & GWP & Normal Boiling Temp. ${ }^{\circ} \mathrm{C}$ \\
\hline HFC32 & 0 & 675 & -52 \\
\hline HFC134a & 0 & 1430 & -26.3 \\
\hline HFC152a & 0 & 124 & -25 \\
\hline HFC407a & 0 & 2107 & -45.2 \\
\hline HFO1234 yf & 0 & 4 & -30 \\
\hline HFO1234 ze(E) & 0 & 6 & -19 \\
\hline HFC410A & 0 & 2088 & -51.6 \\
\hline HFC507A & 0 & 3985 & -46.7 \\
\hline HFC123 & 0.02 & 77 & -27.6 \\
\hline HFC124 & 0.022 & 609 & -12 \\
\hline HFC502 & 0.249 & 4657 & -45 \\
\hline
\end{tabular}


Table 2. Specifications of the adsorbents.

Parameter

ACP Maxsorb III

ACF A-20

Mass, $\mathrm{kg}$

$50.27 \times 10^{-3}$

$50.55 \times 10^{-3}$

Pore volume, $\mathrm{m}^{3} / \mathrm{kg}$

$1.7 \times 10^{-3}$

$1.03 \times 10^{-3}$

Solid density, $\mathrm{kg} / \mathrm{m}^{3}$

2200

800

Surface area, $\mathrm{m}^{2} / \mathrm{kg}$

$3140 \times 10^{3}$

$2000 \times 10^{3}$

Particle diameter, $\mathrm{m}$

$72 \times 10^{-6}$

$21.6 \times 10^{-6}$ 
Table 3. Fitting parameters of Tóth equation.

Parameters ACP/HFC410A ACF/HFC410A

$\begin{array}{lll}C_{0}, \mathrm{~kg} / \mathrm{kg} & 4.18 & 1.68 \\ b_{0}, \mathrm{kPa}^{-1} & 1.4 \times 10^{-6} & 1.84 \times 10^{-6} \\ z & 0.68 & 0.83 \\ H_{s t}, \mathrm{~kJ} / \mathrm{kg} & 237 & 249\end{array}$


Table 4. Fitting parameters of D-A equation.

Parameters ACP/HFC410A ACF/HFC410A

$\begin{array}{lll}W_{0}, \mathrm{~cm}^{3} / \mathrm{g} & 5.96 & 3.25 \\ E, \mathrm{~kJ} / \mathrm{kg} & 59.6 & 72.5 \\ n & 1.17 & 1.43\end{array}$


Table 5. Fitting parameters for combined temperature and loading dependence heat of adsorption.

Parameter ACP ACF

$\begin{array}{lcc}A_{1}, \mathrm{~kJ} / \mathrm{kg} . \mathrm{K} & -0.019 & -0.008 \\ A_{2}, \mathrm{~kJ} / \mathrm{kg} . \mathrm{K} & 10.052 & 2.951 \\ A_{3}, \mathrm{~kJ} / \mathrm{kg} & -1172.2 & -23.792 \\ \beta & 59 & 56\end{array}$


Table 6. Activation energy and pre-exponential coefficient for ACP/HFC410A and $\mathrm{ACF} / 410 \mathrm{~A}$.

Parameter

$\mathrm{ACP}$

$\mathrm{ACF}$

$\begin{array}{ccc}E_{a}, \mathrm{~kJ} / \mathrm{kg} & 16 & 85.4 \\ D_{s 0}, \mathrm{~m}^{2} / \mathrm{s} & 1.3 \times 10^{-13} & 2.8 \times 10^{-13}\end{array}$


Figure captions:

Fig. 1. Schematic diagram of the experimental apparatus for adsorption characterization.

Fig. 2. Fitting of Tóth and D-A with volume correction models with experimental data for ACP/HFC410A.

Fig. 3. Fitting of Tóth and D-A with volume correction models with experimental data for ACF/HFC410A.

Fig. 4. Comparison of adsorption uptake deviations between experimental uptake and calculated uptakes.

Fig. 5. Maximum adsorption capacity based on Tóth equation for six different adsorption pairs.

Fig. 6. Isosteric heat of adsorption at different adsorption temperatures for ACP/HFC410A.

Fig. 7. Isosteric heat of adsorption at different adsorption temperatures for ACF/HFC410A.

Fig. 8. Temperature dependence of fitting parameters of isosteric heat of adsorption in Eq 15.

Fig. 9. Henery's coefficent as a function of 1/T for ACP/HFC410A and ACF/HFC410A.

Fig. 10. Relation between $k_{H}$ and $H_{s t}$.

Fig. 11. Fitting of LDF model with experimental adsorption kinetics at different adsorption temperatures for $\mathrm{ACP} / \mathrm{HFC} 410 \mathrm{~A}$.

Fig. 12 Fitting of LDF model with experimental adsorption kinetics at different adsorption temperatures for $\mathrm{ACF} / \mathrm{HFC} 410 \mathrm{~A}$. 


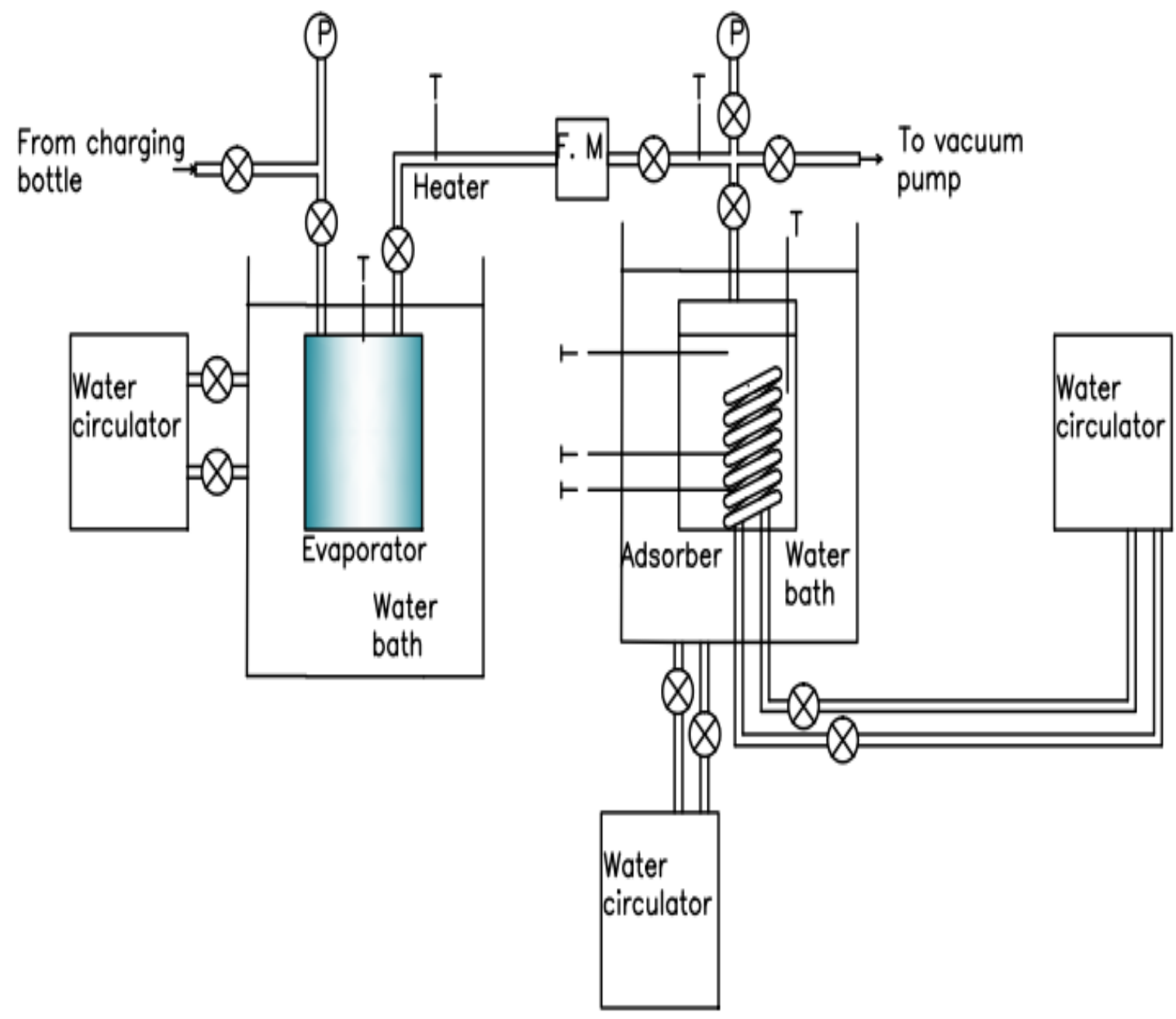

P: Pressure transducer, T: Thermocouple, F.M: Flow meter

Fig. 1. Schematic diagram of the experimental apparatus for adsorption characterization. 


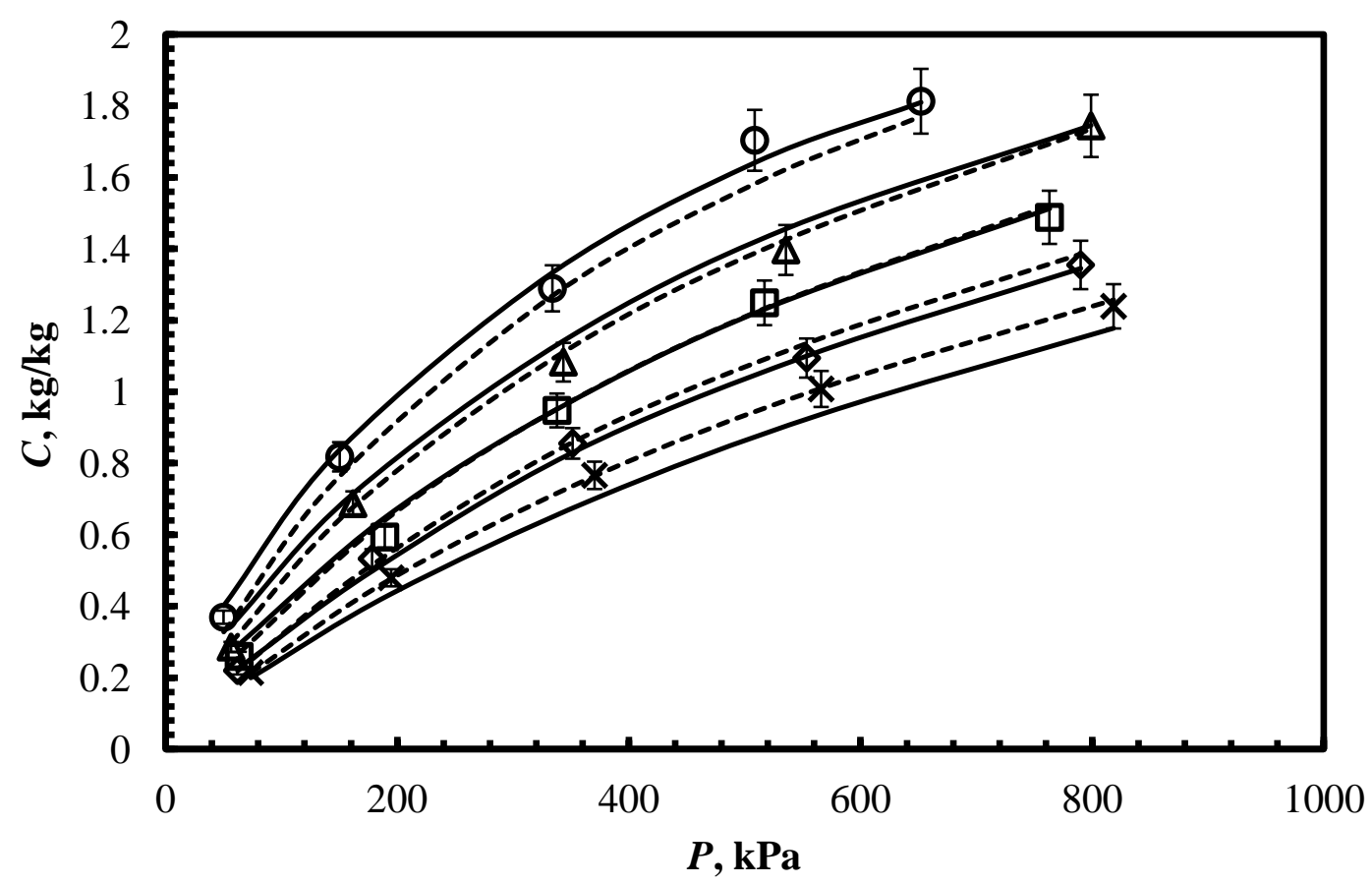

Fig. 2. Fitting of Tóth and D-A with volume correction models with experimental data for ACP/HFC410A.

Legend: O- $10^{\circ} \mathrm{C}, \square-20^{\circ} \mathrm{C}, \square-30^{\circ} \mathrm{C}, \diamond-40^{\circ} \mathrm{C}, \mathrm{x}-50^{\circ} \mathrm{C}$, solid line- D-A equation, dashed linesTóth equation. 


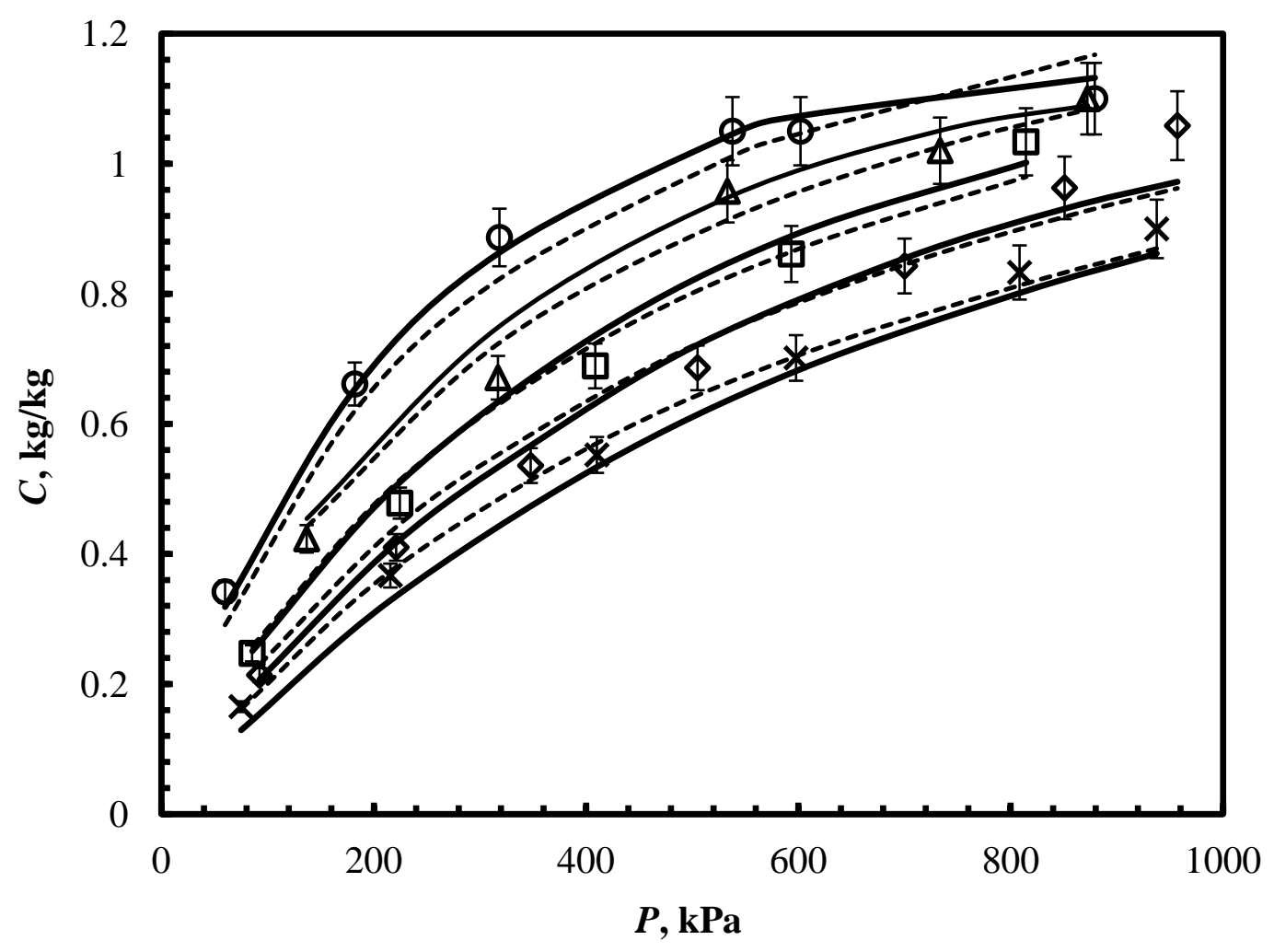

Fig. 3. Fitting of Tóth and D-A with volume correction models with experimental data for ACF/HFC410A.

Legend: O- $10^{\circ} \mathrm{C}, \square-20^{\circ} \mathrm{C}, \square-30^{\circ} \mathrm{C}, \diamond-40^{\circ} \mathrm{C}, \mathrm{x}-50^{\circ} \mathrm{C}$. 


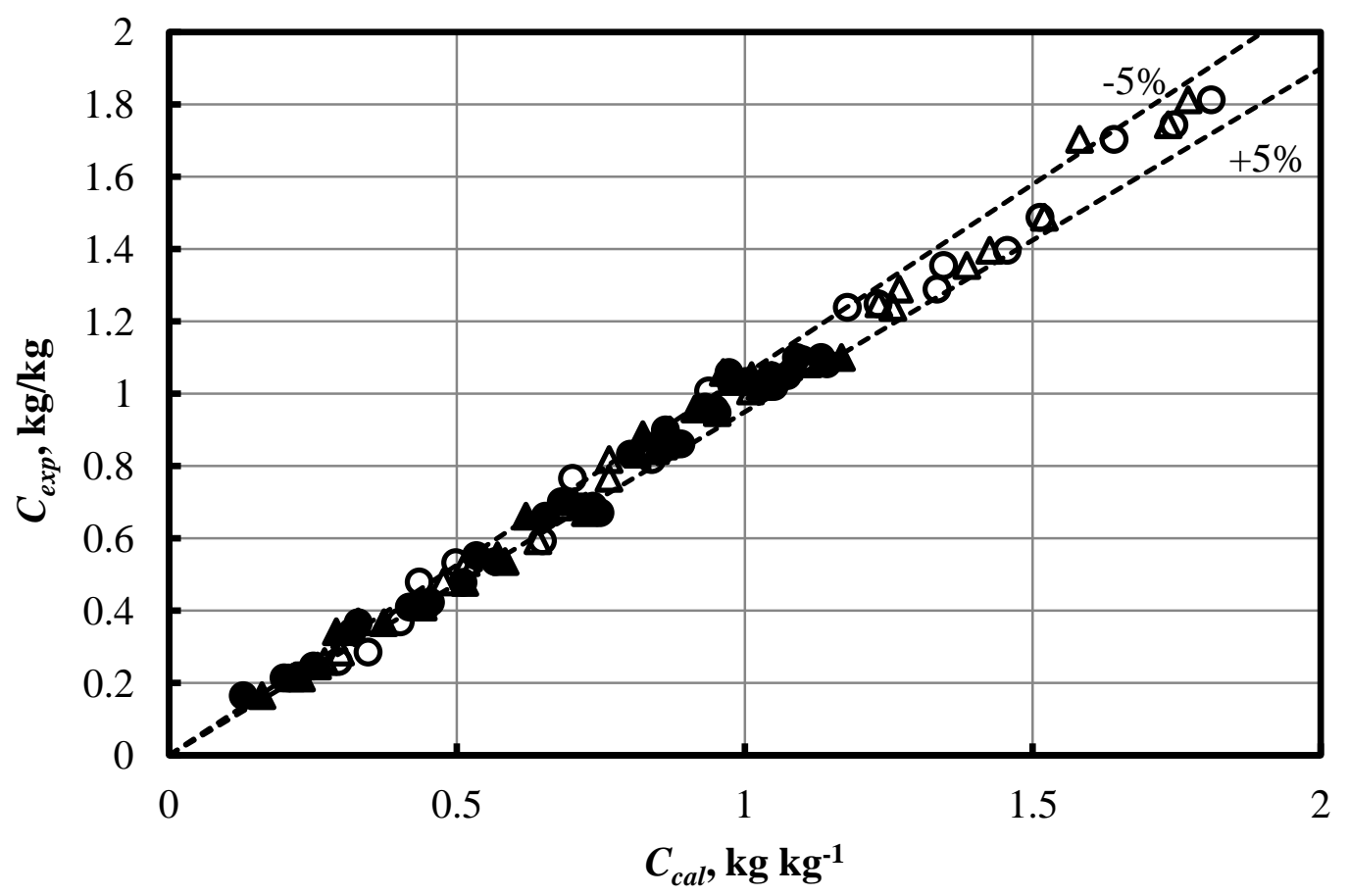

Fig. 4. Comparison of adsorption uptake deviations between experimental uptake and calculated uptakes.

Legend: ACP- open symbols; ACF- filled symbols; O- Tóth equation; $\Delta$ - D-A equation. 


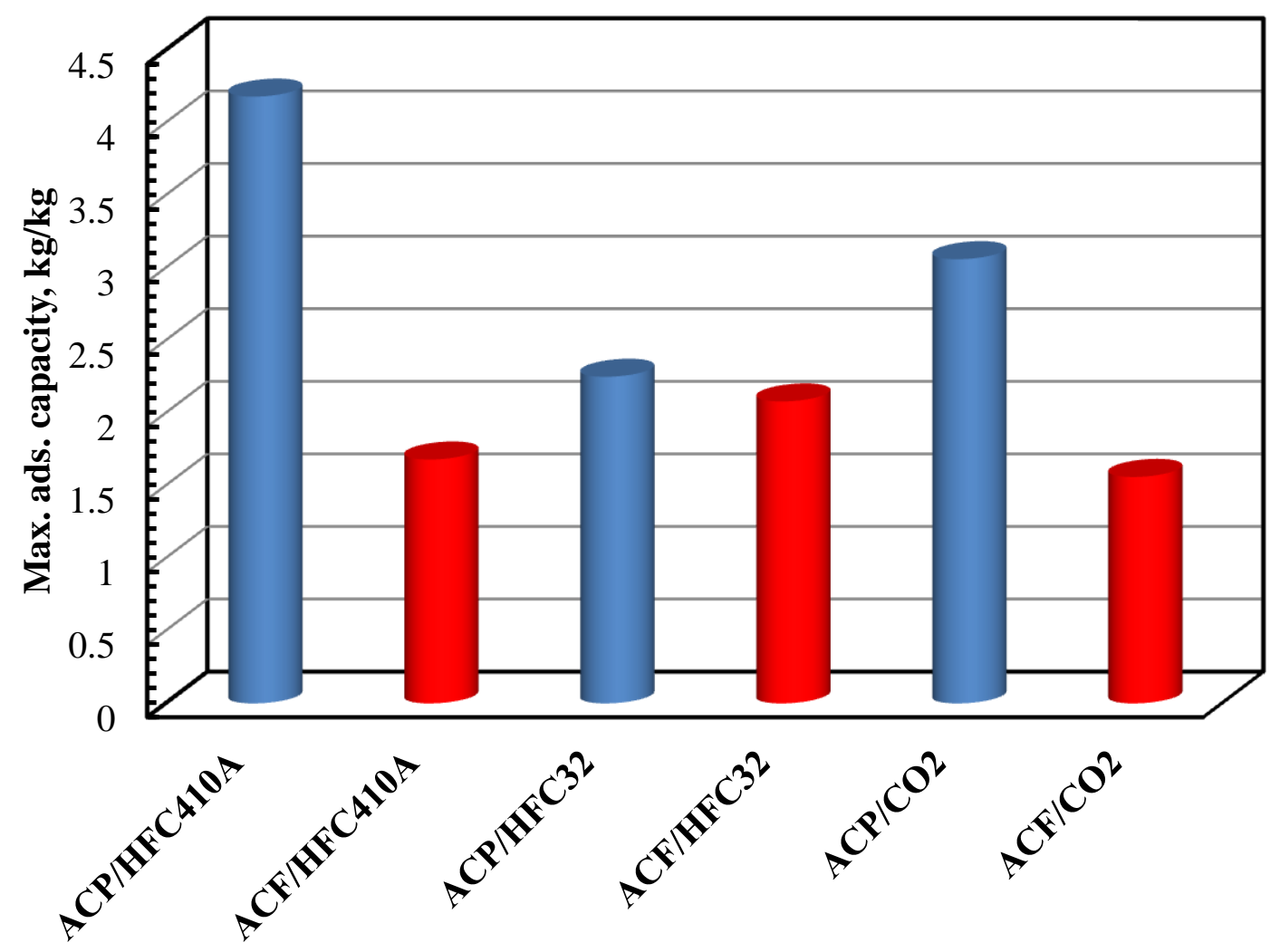

Fig. 5. Maximum adsorption capacity based on Tóth equation for six different adsorption pairs. 


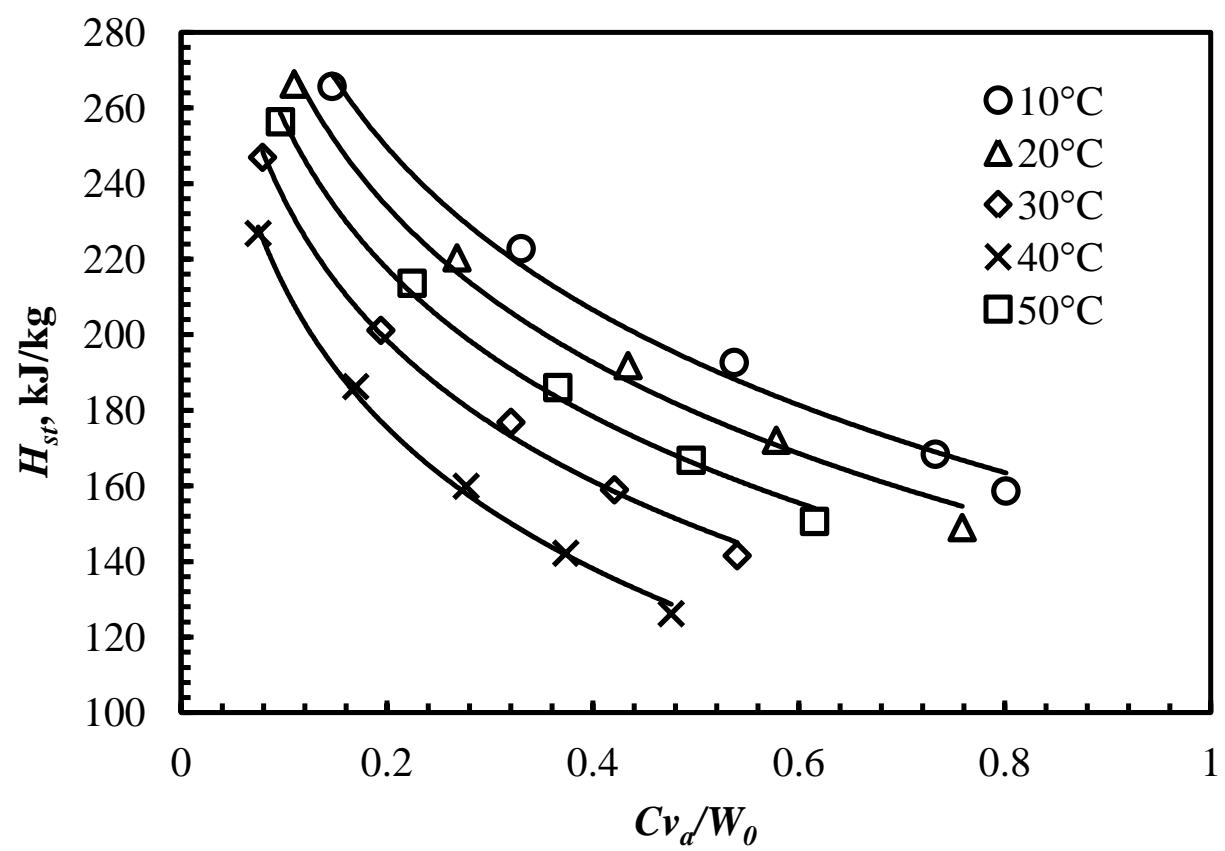

Fig. 6. Isosteric heat of adsorption at different adsorption temperatures for ACP/HFC410A. 


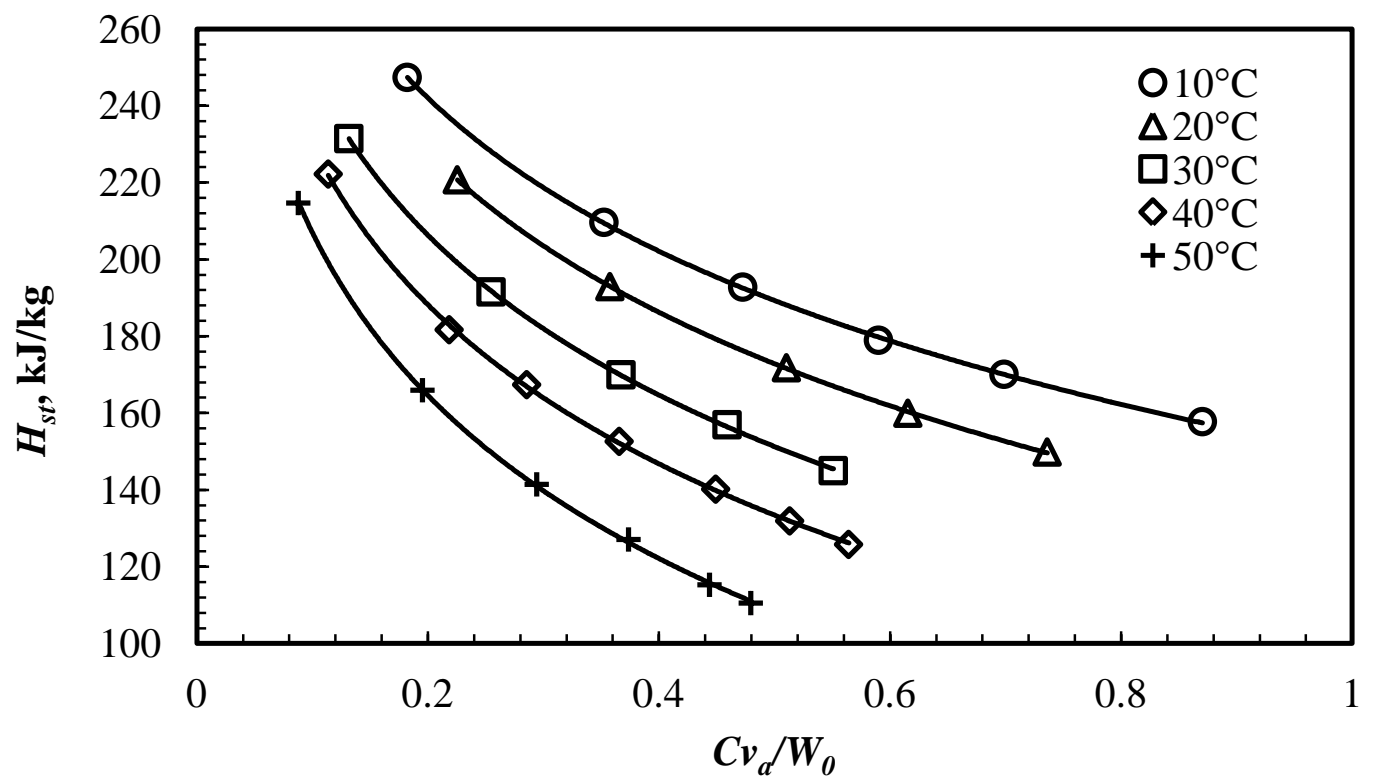

Fig. 7. Isosteric heat of adsorption at different adsorption temperatures for ACF/HFC410A. 


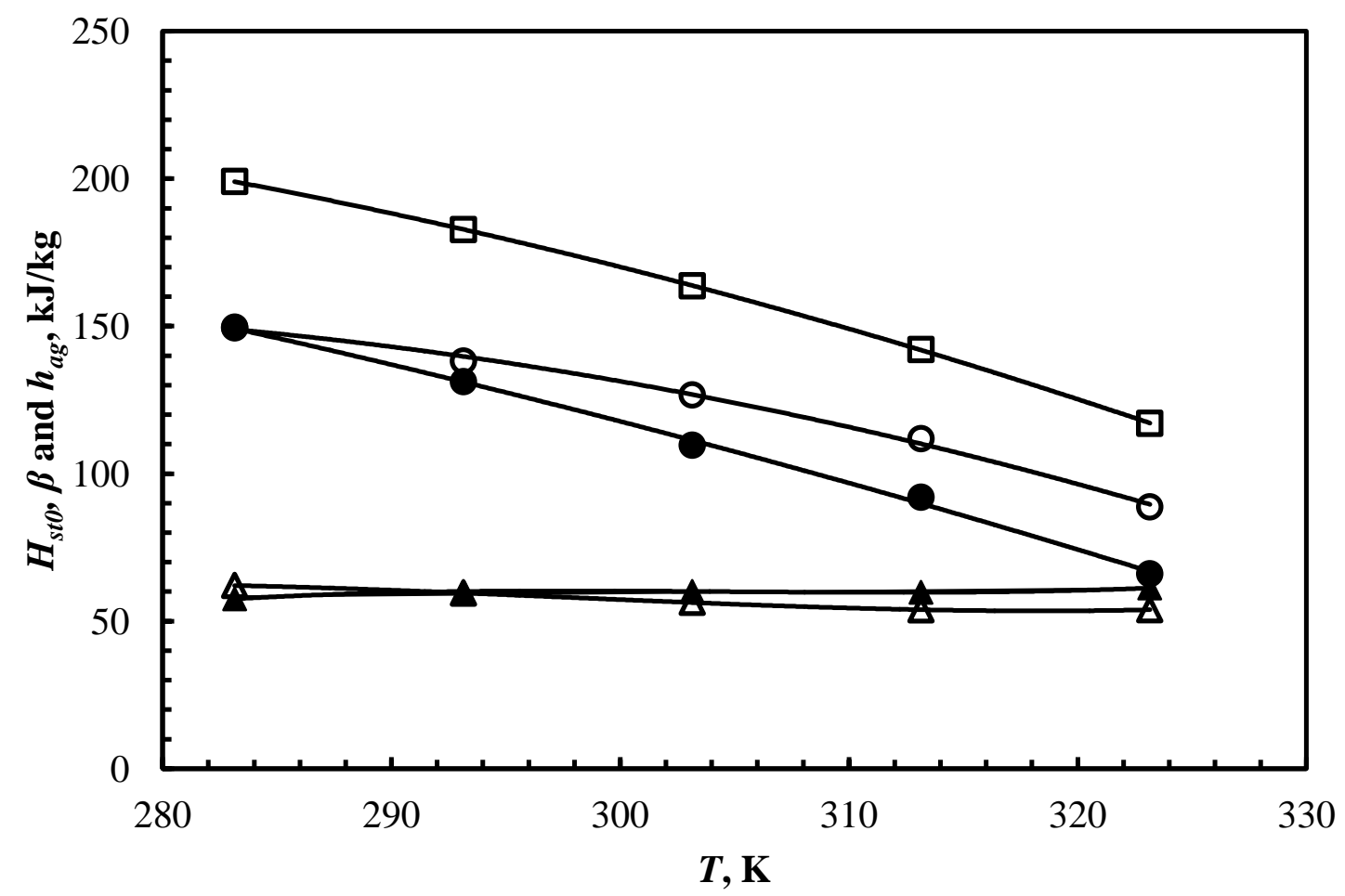

Fig. 8. Temperature dependence of fitting parameters of isosteric heat of adsorption in Eq. 15.

Legend: ACP- open symbols; ACF- Filled symbols; O- $\mathrm{H}_{\text {st } 0} ; \Delta-\beta, \square-h_{a g}$ 


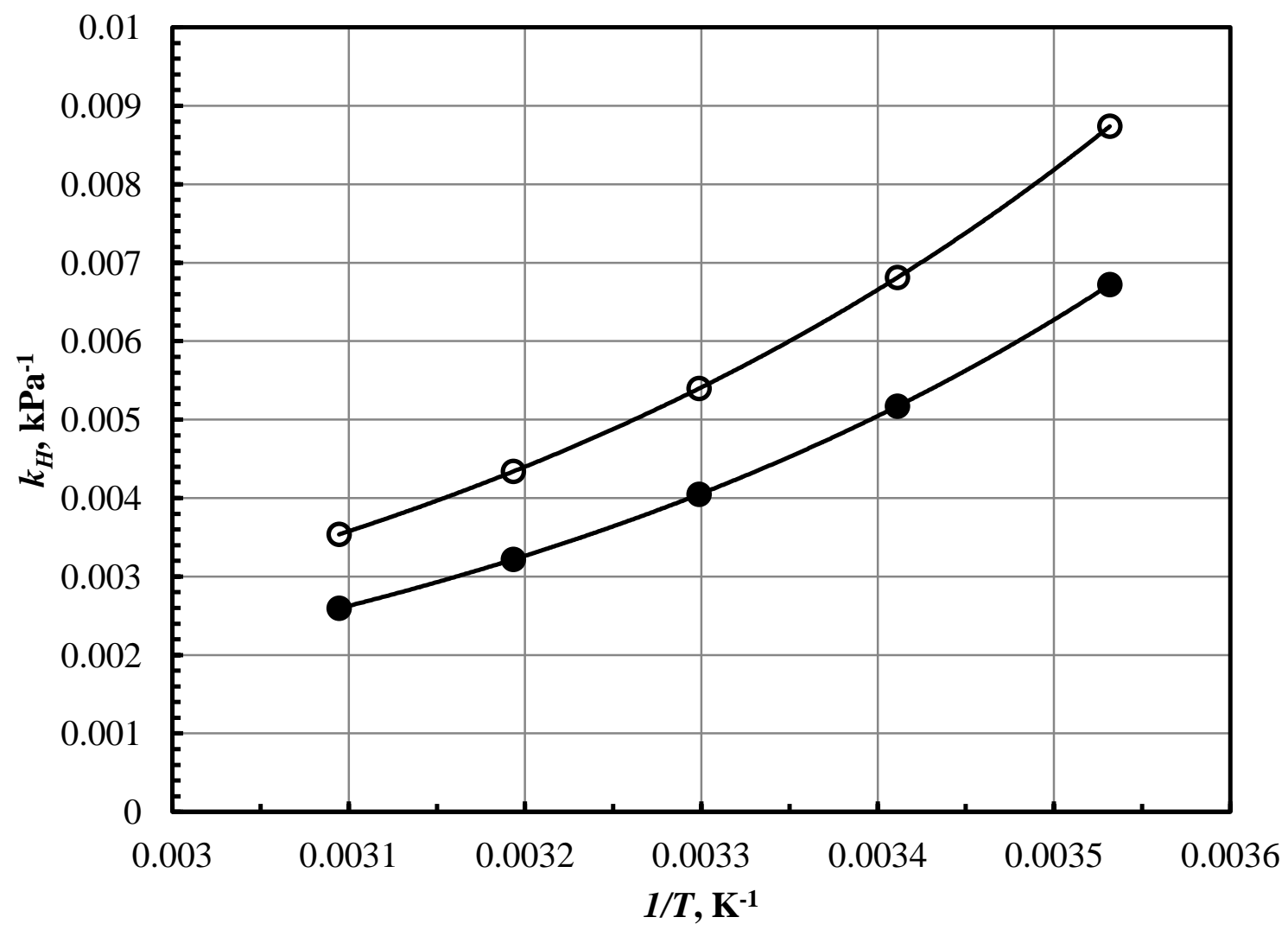

Fig. 9. Henery's law coefficent for ACP/HFC410A and ACF/ HFC410A.

Legend: ACP- open symbols; ACF- filled symbols. 


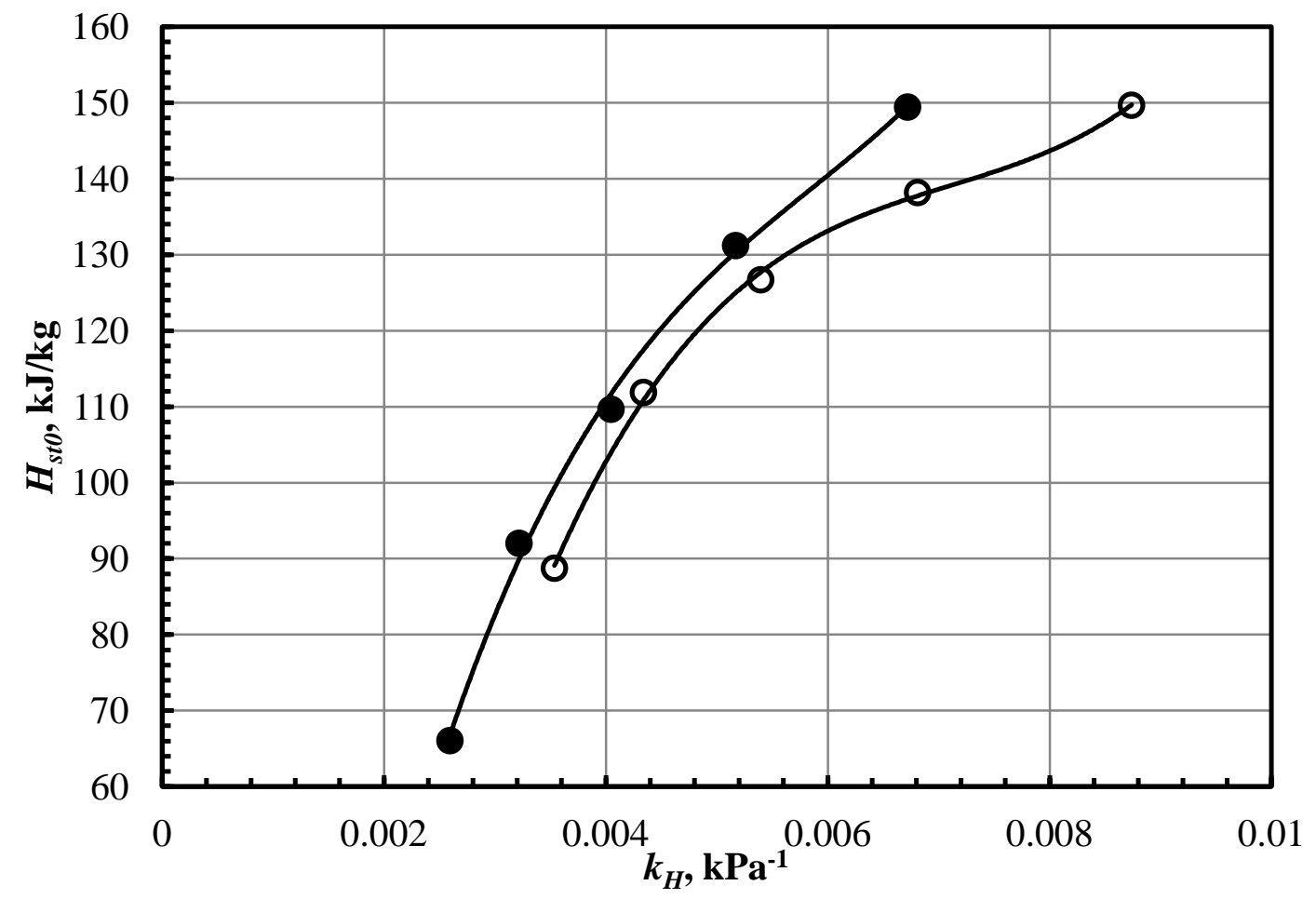

Fig. 10. Relation between $k_{H}$ and $H_{s t 0}$

Legend: ACP- open symbols; ACF- filled symbols. 


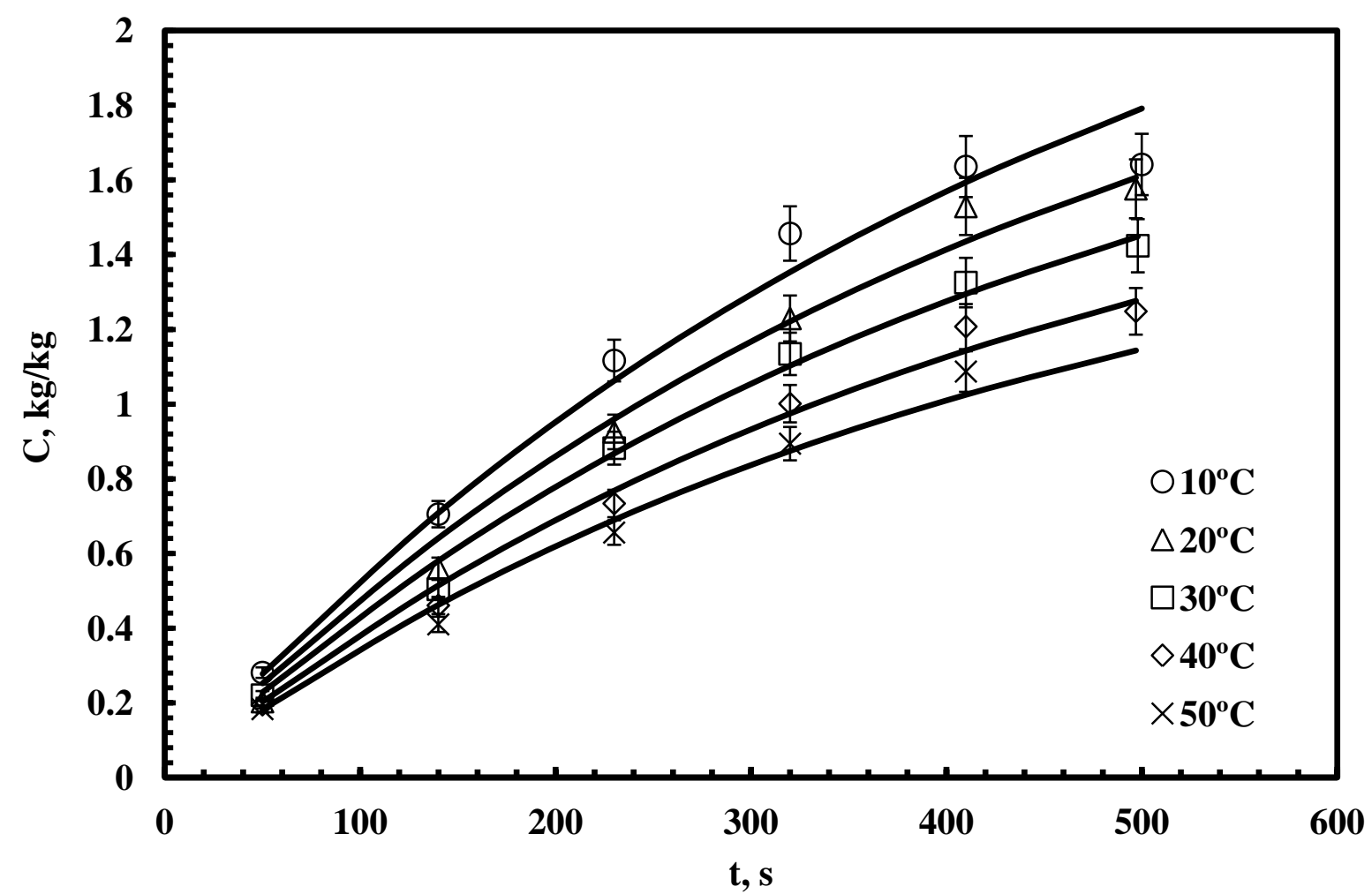

Fig. 11. Fitting of LDF model with experimental adsorption kinetics at different adsorption temperatures for $\mathrm{ACP} / \mathrm{HFC} 410 \mathrm{~A}$. 


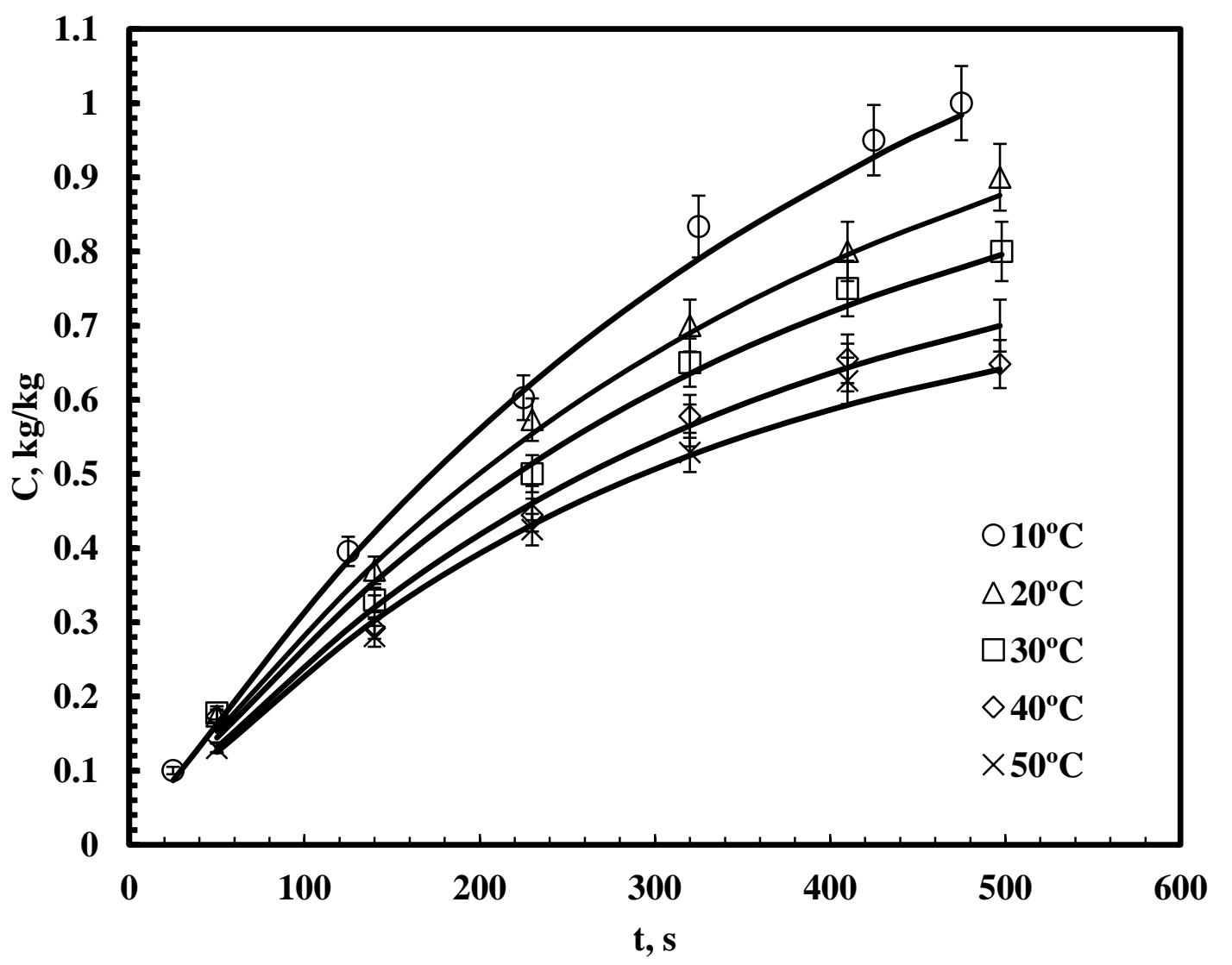

Fig. 12 Fitting of LDF model with experimental adsorption kinetics at different adsorption temperatures for $\mathrm{ACF} / \mathrm{HFC} 410 \mathrm{~A}$. 